\title{
Coulomb Stress Analysis of Halmahera Earthquake on June 7th 2016, Mw=6.3 and Its Correlation with Aftershocks
}

\author{
Fathony Akbar Pratikno ${ }^{1}$, Gazali Rachman ${ }^{2}$, and Bagus Jaya Santosa ${ }^{1}$
}

\begin{abstract}
Main earthquake with magnitude Mw 6.3, has been occurred in the West of Halmahera Island, Northern Molucca on June 7th, 2016. The activity of the Pacific plate, Eurasia plate and Indo-Australia plates trigger some earthquake around Halmahera. The purpose of the current study was to determine the Coulomb stress change of the main earthquake and predict the aftershocks' location around it. For understanding an interaction of the faults, this study used Coulomb stress change model. Three component seismic waveform data recorded by TNTI station within $132 \mathrm{~km}$, SANI station within $381.2 \mathrm{~km}$, LUWI station within $478.3 \mathrm{~km}$, and TOLI2 station within $617.6 \mathrm{~km}$ of the epicenter. This study used software ISOLA-GUI to obtain the parameters of the earthquake source. The parameters of the earthquake source were then used to determine fracture orientation, length, width and slip displacement. It was also used to calculate the Coulomb stress changes around the main shock, using software Coulomb 33. The result shows that the orientation of the earthquake fault has a dip angle of $48^{\circ}$ to the horizontal plane and has a strike of $210^{\circ}$ against the North. The fault length is $19.49 \mathrm{~km}$, the fault width is $11.59 \mathrm{~km}$ and slip displacement is $49.43 \mathrm{~cm}$. Based on plotting result, the main earthquake in Northern Molucca on June 7th, 2016 has positive Coulomb stress change that spread across the Northeast to the Southwest. This change is likely triggered three aftershocks with a range of Mw 4.7 to 6.2.
\end{abstract}

Keywords—Aftershock, Coulomb Stress Change, Earthquake, Halmahera Island and Moment Tensor.

\section{INTRODUCTION}

$\mathrm{T}$ he Molucca Sea is located in the western Pacific Ocean, located near Molucca province, Indonesia. Tectonically, Halmahera Island situated between three plates, namely Indo-Australia plate, the Eurasian plate and the Pacific plate, as shown in Figure 1. This is the region with high and complex seismicity level [1]. In the northern part of North Maluku, there are several microplates that affect seismicity in the Halmahera archipelago, namely the Sangihe microplate, the Halmahera microplate and the Molucca Sea microplate. These three microplates are fragments of Eurasian and Pacific plates which thrust against each other and cause several earthquake around Halmahera Island.

Earthquake events are closely related to fault interaction, rock deformation, or tectonic activity. A widely used model for explaining fault interactions is the Coulomb stress change. Fault interactions and triggering caused by earthquake rupture have been studied in Indonesia in the past few years, such as Aceh earthquake [2], tectonic earthquake around Merapi volcano [3], and tectonic earthquake around Gamalama and Soputan volcano [4]. Increasing Coulomb stress places on the region most likely to identify aftershocks in the days following a mainshock. The Coulomb stress changes analysis predicts an increased probability of aftershocks, occurring some distance from the mainshock hypocenter.

In this article, we present local waveform data analysis of Northern Molucca earthquake in June $7^{\text {th }} 2016$. Three component seismic waveform data recorded by four stations (TNTI, LUWI, SANI and TOLI2), to estimate the source parameters from the main earthquake. Moreover, focal mechanism will be estimated to reveal

${ }^{1}$ Fathony Akbar Pratikno and Bagus Jaya Santosa are with Departement of Physics, Institut Teknologi Sepuluh Nopember, Surabaya, 60111, Indonesia. E-mail: bjs@physics.its.ac.id.

${ }^{2}$ Gazali Rachman is with Departement of Physics Education, Universitas Patimura, Ambon, 97233, Indonesia. E-mail: gazali.rachman@gmail.com.

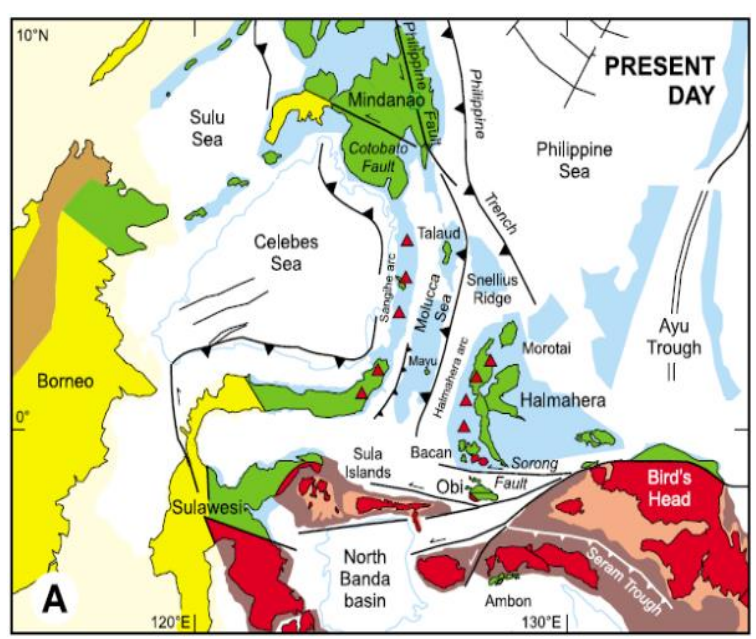

Figure 1. Tectonics system around Halmahera Island.

the parameters of fault, Coulomb stress change, and aftershocks in area around the hypocenter.

\section{METHOD}

\section{A. Data Preparation}

Characteristics of earthquakes can be determined from the parameters of the earthquake. The seismic source parameters are obtained by analyzing earthquake data which is recognized as seismic waves. The seismic waves generating from the center point of the earthquake (hypocenter) and recorded by stations installed around the area of frequent earthquakes [5].

For analyzing seismic wave from Halmahera earthquake on June 7th, 2016, it used three component seismic waveform data recorded by TNTI station within $132 \mathrm{~km}$, SANI station within $381.2 \mathrm{~km}$, LUWI station within $478.3 \mathrm{~km}$, and TOLI2 station within $617.6 \mathrm{~km}$ from the epicenter. This earthquake data is requested from earthquake database website geofon.gfzpotsdam.de which provided three component seismic waveform data (BHN, BHE and BHZ). 
TABLE 1.

NORTHERN MOLUCCA CRUSTAL MODEL

\begin{tabular}{cccccc}
\hline \hline $\begin{array}{c}\text { Depth } \\
(\mathbf{k m})\end{array}$ & $\begin{array}{c}\mathbf{V p} \\
(\mathbf{k m} / \mathbf{s})\end{array}$ & $\begin{array}{c}\text { Vs } \\
(\mathbf{k m} / \mathbf{s})\end{array}$ & $\begin{array}{c}\text { Density } \\
\left(\mathbf{g r} / \mathbf{c m}^{\mathbf{3}}\right)\end{array}$ & $\mathbf{Q p}$ & $\mathbf{Q s}$ \\
\hline 0.00 & 2.33 & 1.32 & 2.5 & 300 & 150 \\
1.00 & 4.29 & 2.41 & 2.9 & 300 & 150 \\
2.00 & 5.61 & 3.11 & 3.0 & 300 & 150 \\
5.00 & 6.48 & 3.92 & 3.3 & 300 & 150 \\
16.00 & 6.54 & 3.93 & 3.4 & 300 & 150 \\
33.00 & 7.16 & 4.47 & 3.4 & 300 & 150 \\
40.00 & 8.02 & 4.48 & 3.5 & 600 & 300 \\
100.00 & 8.02 & 4.49 & 3.3 & 600 & 300 \\
\hline \hline
\end{tabular}

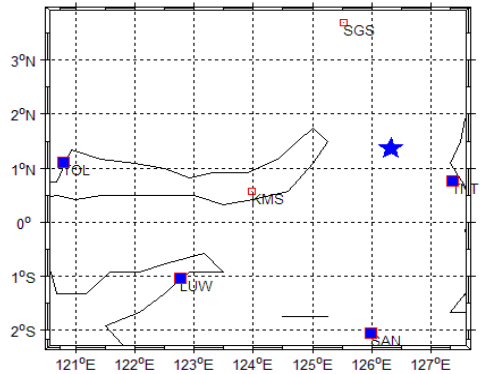

Figure 2. The Location of Main Earthquake and Recording Station.

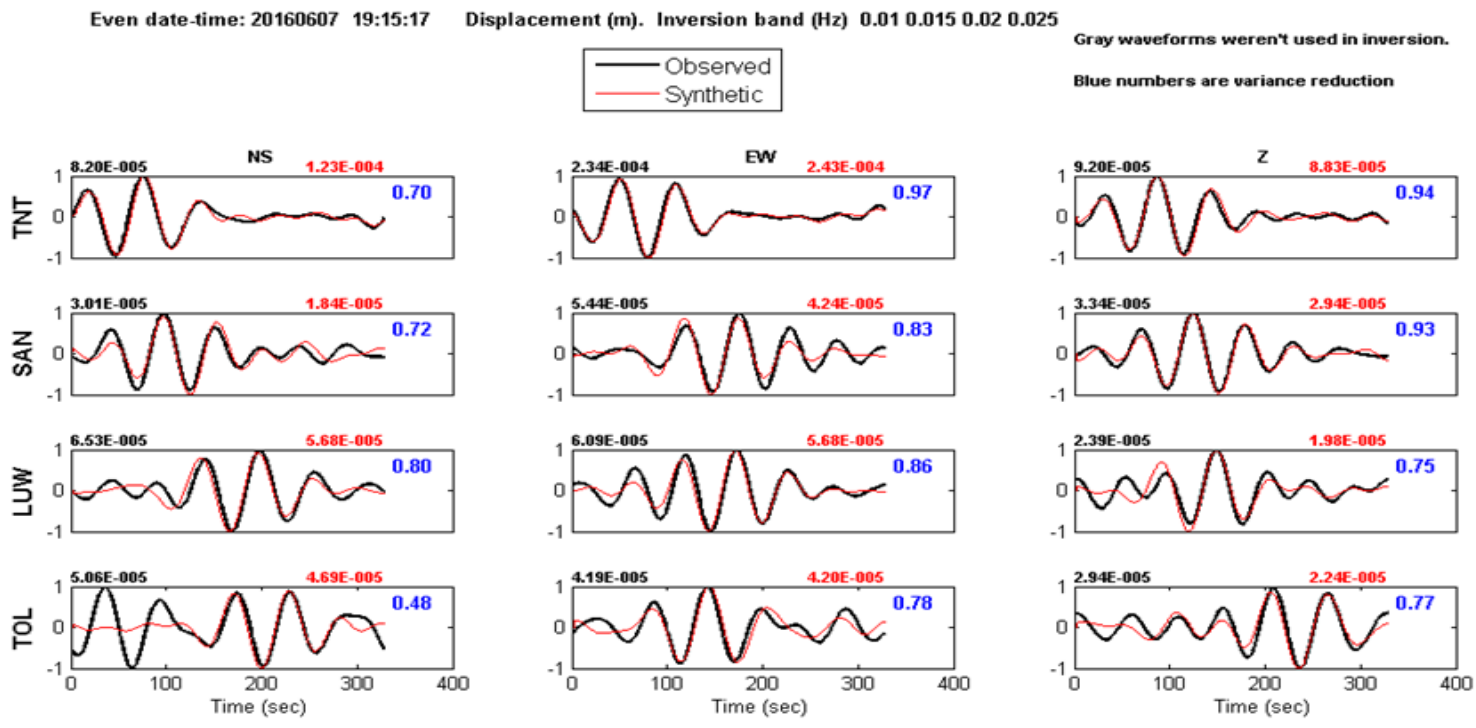

Figure 3. Observed and synthetic seismogram data 3 components to all four stations.

\section{B. Moment Tensor Inversion}

Flows of each stage of data processing are presented by ISOLA software. Starting from conversion and data preprocessing, inputting data, Green function calculation, moment tensor inversion and plotting the results [6].

The data inputting process in ISOLA-GUI starts from the determining the crustal model (Table 1), event input, selecting stations, inputting observed data, and trial input seismic sources by selecting a single source. The position earthquakes epicenter and recording station are illustrated in Figure 2.

To obtain earthquake source parameters, the inversion is using frequency band $\mathrm{f} 1: 10 \mathrm{mHz}, \mathrm{f} 2: 15 \mathrm{mHz}, \mathrm{f} 3: 20$ $\mathrm{mHz}$ and f4: $25 \mathrm{mHz}$. Earthquake source parameters will later be used to determine the orientation, fault plane length and width and also slip length of both earthquakes. To determine real fault plane orientation, HC-plot method is used.

\section{Coulomb Stress Change}

We used Coulomb 3.4 software to calculate Coulomb stress change, shear stress and normal stress changes on the source fault plane. Earthquake parameters obtained from ISOLA-GUI method is used as an input for Coulomb 3.4 program. Coulomb stress changing distribution around the fault can be used to predict locations and magnitude of the aftershocks.

\section{RESULTS AND DISCUSSION}

\section{A. Moment Tensor Solution}

Earthquake characteristic can be known from the earthquake source parameters. Earthquake source parameters obtained by analyzing earthquake data that is well known by the term seismic wave [7]. We analyzed source parameters of Halmahera earthquake on June 7th, 2016. Correlation between 3 components seismogram waveforms at four recording stations and the synthetic seismogram is presented in Figure 3. Better results are obtained when the observation data (black curve) fit with the synthetic data (red curve).

A good waveform fitting can be discovered by the value of the variance reduction, which is greater than $65 \%$ [5]. The greater the variance reduction value indicate a better fitting, it means that the match value between observation data and synthetic data is higher. In this research, we obtained the reduction variant value of $89.05 \%$ with a DC value of $86.1 \%$, these value can be seen at Figure 4.

Those values indicate the resulted seismogram fitting that in this research is appropriate to all four recording stations. Therefore, the result of this research is appropriate to estimate earthquake source parameters such as moment seismic, hypocenter, magnitude, moment tensor, strike, dip and rake as illustrated by Figure 4.

\section{B. HC-Plot of Main Earthquake}

Centroid Moment tensors (CMT) parameters that tested to get the actual fault planes are the orientation of fault plane 1 and fault plane 2. Between these two planes there is only one nodal plane that representing the actual fault plane. Figure 5 below shows an illustration of the real fault area (activated fault) using the HC-plot method.

The result from ISOLA-GUI and HC-Plot method shows that the orientation of the earthquake fault has a dip angle of $48^{\circ}$ to the horizontal plane, a strike of $210^{\circ}$ against the North and a rake of $103 \mathrm{o}$. Based on the 

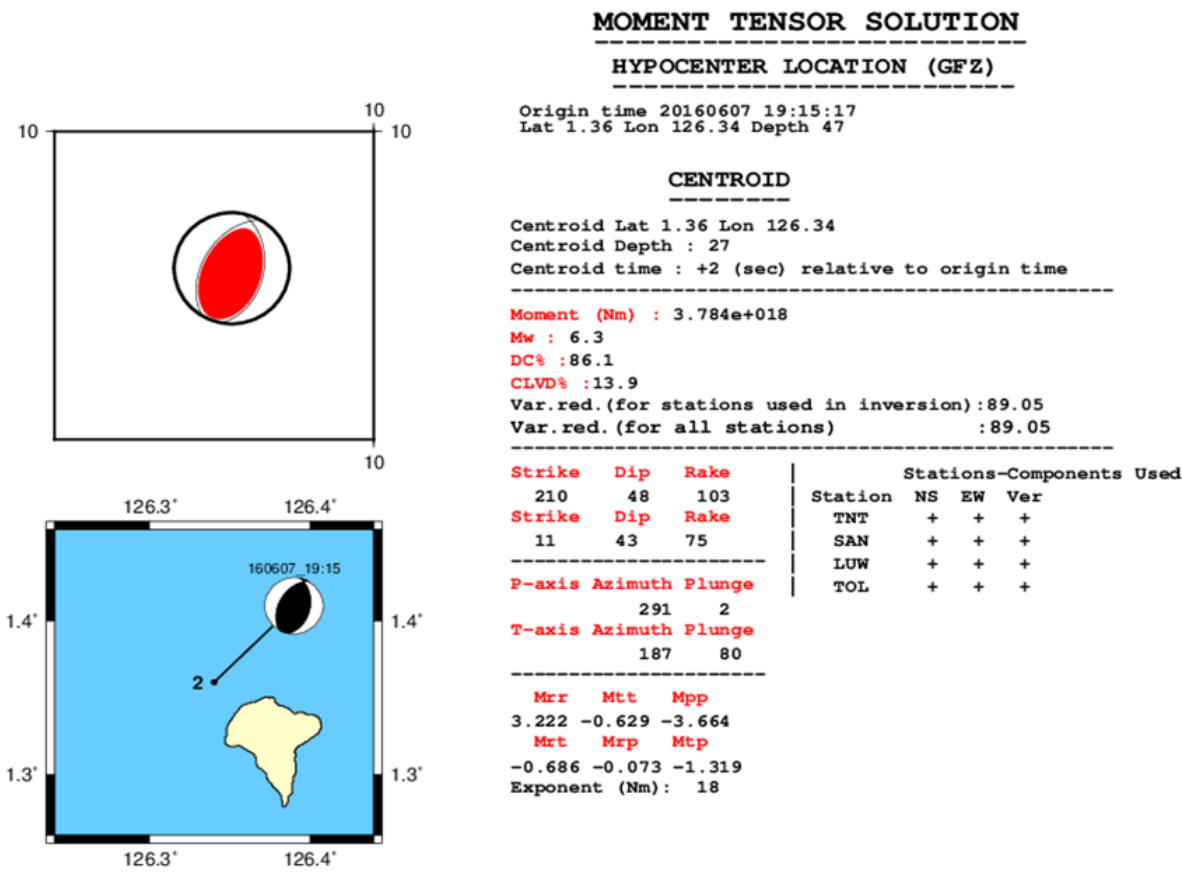

Figure 4. Moment Tensor Solution of the Main Earthquake.

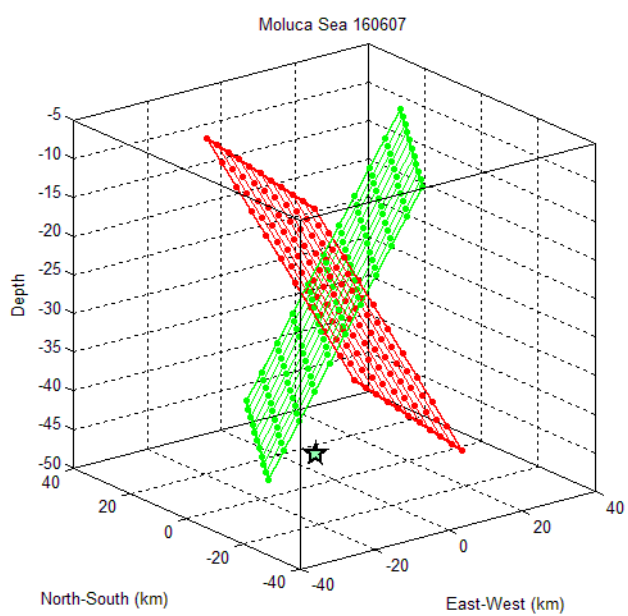

Figure 5. Identification of the Main Earthquake with HC-Plot Method.

appearance of the beach ball generated by ISOLA-GUI in Figure 4, it can be predicted that the fault type of the main earthquake is an oblique reverse fault.

\section{Coulomb Stress Change Solution}

Furthermore, using the empirical relations implemented in the Coulomb [8], obtained the length and width of fault plane respectively $19.50 \mathrm{~km}$ and $11.59 \mathrm{~km}$ and displacement slip of $49.43 \mathrm{~cm}$. The coulomb failure stress change can be defined as follows [9]:

$$
\Delta \mathrm{CFS}=\Delta \tau+\mu^{\prime} \Delta \sigma \mathrm{n}
$$

where $\Delta \tau$ is the shear stress change on a given failure plane (positive in the fault slip direction). $\Delta \sigma \mathrm{n}$ is the normal stress change (positive for fault unclamping or compression). $\mu^{\prime}=\mu(1-\beta)$ is the effective coefficient of friction, which includes the effects of pore pressure changes and generally ranges from 0 to 0.8 .

The previous study showed that the $\mu^{\prime}$ is typically found to be around 0.4 for subduction zones [10]. Figure 6 shows Coulomb stress change distribution of Halmahera earthquake on June 7th, 2016 with depth of $47 \mathrm{~km}$ and Mw: 6.3.

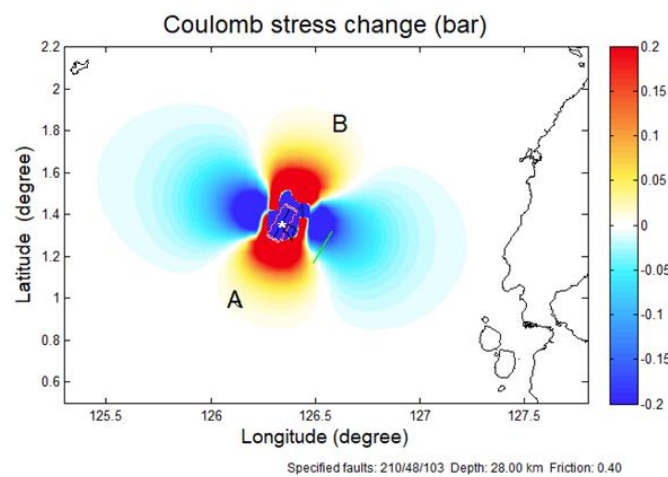

Figure 6. Coulomb stress change distribution of the main earthquake.

\section{Prediction of Aftershock}

The results of coulomb stress change of the earthquake in four field lobe consists of two lobe fields positive and two lobe field negative. Lobe positive value marked in red is an area of stress increase of 0.01 bar to 0.2 bar in the southwest and northeast. So that, the affected area coulomb stress distribution of positive changes produce aftershocks which are caused by stress increases due to the earthquake of $\mathrm{Mw}=6.3$. While the negative lobe marked with blue color which is an area the stress drop from 0.01 bar to 0.2 bar as shown in Figure 6 .

The aftershocks are predicted to be in red lobes zone scattered in the Northeast and Southwest of the main earthquake. There are 3 events that are predicted to be the aftershocks, the distribution of aftershocks are shown in Figure 7a. Figure 7b shows the focal mechanism of the aftershocks, from the focal mechanism solution that illustrated by the beach ball, we can determine the fault type of each aftershock. The aftershock around the research area is mostly an earthquake with a type of oblique reverse fault, this can be determined from the model of beach ball that has a dark area in the center of the ball. 


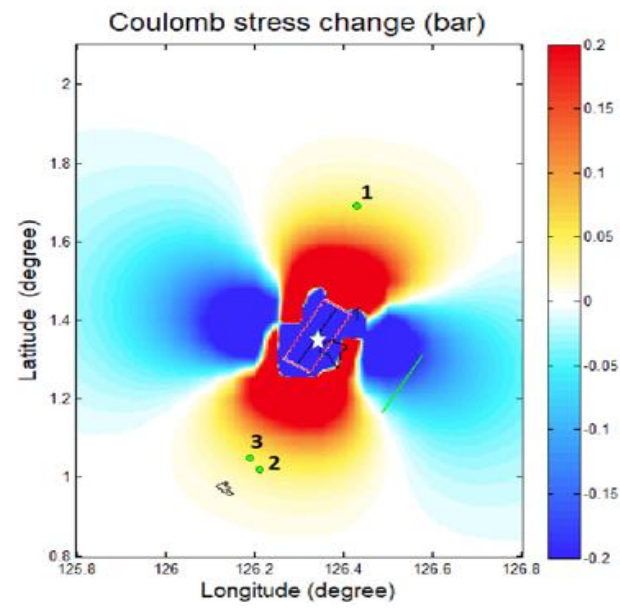

(a)

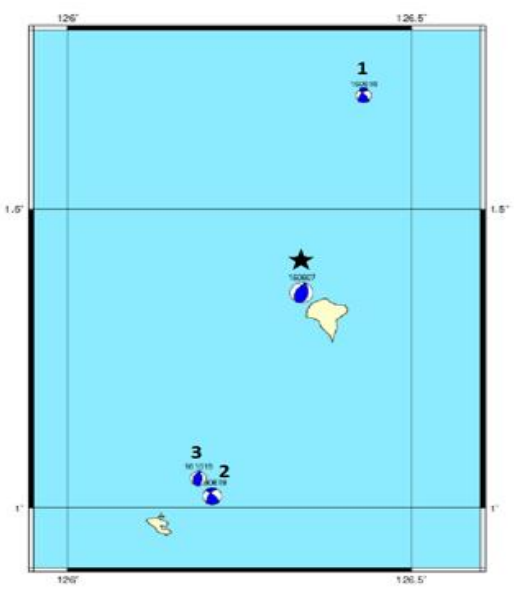

(b)

Figure 7. (a) Aftershock distribution of the Main Earthquake, (b) Focal Mechanism of the Aftershock.

\section{CONCLUSION}

Halmahera earthquake on June 7th, 2016 has an orientation of the earthquake fault dip angle of $48^{\circ}$, a strike of $210^{\circ}$ and a rake of $103 \mathrm{o}$. The length and width of fault plane respectively $19.50 \mathrm{~km}$ and $11.59 \mathrm{~km}$, with displacement slip of $49.43 \mathrm{~cm}$. Based on plotting result, the main earthquake has positive Coulomb stress change that spread across the Northeast to the Southwest. This change is likely triggered three aftershocks with a range of Mw 4.7 to 6.2 .

\section{ACKNOWLEDGEMENT}

Author thanks to GEOFON for providing seismic and supporting data.

\section{REFERENCE}

[1] M. L, A. Yustesia, and Suwardi, "Sistem Tektonik Dan Implikasinya Terhadap Gempa Bumi Di Pulau Halmahera," J. Pendidik. Geogr., vol. 23, no. 1, pp. 20-29, 2015.

[2] Madlazim, "Coulomb Stress Changes Due to Recent Aceh Earthquakes," J. Penelit. Fis. dan Apl., vol. 5, no. 1, pp. 914, 2015.

[3] F. Puspasari and W. Wahyudi, "Distribusi coulomb stress akibat gempabumi tektonik selatan Pulau Jawa berdasarkan data gempa tektonik 1977-2000," J. Fis. dan Apl., vol. 13, no. 2, p. 74, Jun. 2017.
D. Sinaga, M. Zarlis, M. Sitepu, R. A. Prasetyo, and A. Simanullang, "Coulomb Stress Analysis of West Halmahera Earthquake $\mathrm{Mw}=7.2$ to Mount Soputan and Gamalama Volcanic Activities," in IOP Conf. Series: Earth and Environmental Science, 2017.

[5] Madlazim and B.J. Santosa, "Estimasi Parameter Sumber Gempa Bumi Padang 30 September 2009, Mw=7,6 dan Korelasinya dengan Aftershocks-nya," J. Mat. Sains, vol. 19, no. 3, pp. 88-93, 2014.

[6] J. Santosa, "Analysis of Three Components Waveform to Invert the Moments Tensor of Earthquakes in Java 2010," Geosciences, vol. 3, no. 1, pp. 13-22, 2013.

[7] B.J. Santosa, "Fault Plane Identification Using Three Components Local Waveforms," Int. J. Geosci., vol. 4, pp. 993-1001, 2013

[8] S. Toda, R. S. Stein, P. A. Reasenberg, J. H. Dieterich, and A. Yoshida, "Stress transferred by the $1995 \mathrm{Mw}=6.9$ Kobe, Japan, shock: Effect on aftershocks and future earthquake probabilities," J. Geophys. Res. B Solid Earth, vol. 103, no. 10, pp. 24543-24565, 1998.

[9] M. Mullick and D. Mukhopadhyay, "Quantitative Analysis of the Nepal Earthquake on 25 April, 2015 in the Perspective of Future Earthquake Hazard," Geod. Geodyn., vol. 8, pp. 7783, 2017.

[10] J. Wu, Y. Cai, W. Li, and Q. Feng, "Strong Aftershock Study Based on Coulomb Stress Triggering-A Case Study on the 2016 Ecuador Mw 7.8 Earthquake," Appl. Sci., vol. 7, p. 1, 2017. 